DARIUSZ ZAJĄC

ORCID 0000-0002-3515-1779

Uniwersytet Kazimierza Wielkiego

w Bydgoszczy

\title{
ETYKA ZAWODOWA NAUCZYCIELI - MIĘDZY UNIWERSALIZMEM A PLURALIZMEM
}

\begin{abstract}
AвSTRACt. Zając Dariusz, Etyka zawodowa nauczycieli - między uniwersalizmem a pluralizmem [Professional Ethics of Teachers - Between Universalism and Pluralism]. Studia Edukacyjne nr 54, 2019, Poznań 2019, pp. 297-310. Adam Mickiewicz University Press. ISSN 1233-6688. DOI: 10.14746/se.2019.54.17

Professional ethics of teachers is one of the most important areas of interest of pedeutology. Not only traditions of that profession, but also the contemporary challenges facing it seem to be indicative of it. In the considerations presented, professional ethics of teachers is shown from two perspectives, i.e. the universal and the pluralistic ones. Each of these perspectives is characterized by diverse understanding of professional ethics of teachers and, in particular, its nature. Generally speaking, the first of these perspectives can come down to the establishment of professional ethics of teachers in the form of a code, while the other moves away from such a strictly code-orientated perception of ethics. Certainly, this does not mean a rejection of any ethical stipulations characteristic of teacher circles, but rather adopting a position according to which such exclusive and only correct stipulations do not exist, but there are a lot of them, which one should bear in mind characterizing the ethical aspects of the teaching profession.
\end{abstract}

Key words: professional ethics of teachers, universalism, pluralism, code of ethics, universal pluralism

\section{Wprowadzenie}

Etyka, a w szczególności problemy w nią wpisujące się, to materia niezwykle delikatna i subtelna, a jednocześnie istotna zarówno z epistemologicznego, jak i społecznego punktu widzenia, co z kolei wskazuje na jej ważkość nie tylko dla teorii, ale w szczególności praktyki edukacyjnej. Kwestie etyczne, zwłaszcza ich wszelkie rozstrzygnięcia (niejednokrotnie dyskusyjne, a czasami wręcz kontrowersyjne) nie należą do łatwych, a tym bardziej jednoznacznych. Problemy natury etycznej ujmowane zarówno w skali mega- poprzez makro- i mezo- do mikropłaszczyzny wzbudzały 
i nadal wzbudzają liczne dyskusje oraz spory wśród badaczy zajmujących się etycznym i moralnym wymiarem współczesnego świata, w szczególności zaś zachodzących w nim przeobrażeń, zarówno w odniesieniu do poszczególnych środowisk, instytucji, grup społecznych, czy wreszcie pojedynczych jednostek.

Można to również odnieść do uprawiania poszczególnych zawodów, głównie tych, w których mamy do czynienia z bezpośrednimi relacjami interpersonalnymi. Niewątpliwie do takich należy zawód nauczyciela. Jego tradycje zdają się zaświadczać, jak doniosłe miejsce zajmują, czy też powinny zajmować, zagadnienia etyczne wpisujące się $\mathrm{w}$ jego istotę, sens i znaczenie.

Niniejsze rozważania stanowią zaledwie skromną próbę podejścia do etyki zawodowej nauczyciela, biorąc pod uwagę dwie perspektywy jej postrzegania. Stąd, celem prezentowanych w tym miejscu eksploracji jest próba ukazania etyki zawodowej nauczyciela $\mathrm{w}$ perspektywie uniwersalnej oraz pluralistycznej, a także możliwość synkretycznego podejścia do wspomnianej etyki. W przedstawianych rozważaniach autor pomija rozpatrywanie etyki zawodowej nauczycieli w wersji relatywistycznej, aczkolwiek należy mieć na względzie, iż współcześnie istnieją również stanowiska opowiadające się za taką jej postacią, zgodnie z którą wszelkie obwarowania etyczne w zawodzie nauczycielskim są tylko wyrazem określonych preferencji. Stąd wniosek, że nie istnieją zatem obiektywne zasady etyczne charakterystyczne dla reprezentantów tego zawodu, do przestrzegania których byliby oni niejako zobligowani, a co najwyżej zasady te mają charakter subiektywny. Zagadnienie to wymaga jednak odrębnych studiów i analiz, których zakres wykraczałby poza ramy przyjęte $w$ tytule niniejszych rozważań Tym niemniej, jawią się one jako dość interesujące i stąd skłaniają też do naukowego rozpoznania, a tym samym osadzenia w dorobku myśli etyczno-pedeutologicznej.

\section{Uniwersalna etyka zawodowa nauczycieli}

Kategoria "uniwersalizmu” pochodzi od łacińskiego słowa universalis i oznacza powszechny, wszystko obejmujący, nie dopuszczający żadnej jednostronności. $Z$ etymologicznego punktu widzenia stanowi wyraz pochodny o dwóch źródłosłowach: unum - jedno i vertere - obracać, a zatem właściwie tłumaczone oznacza obracający się koło jednego, nastawiony na jedność, zwrócony ku jednemu, całościowy, wszechogólny, zawierający się w powszechności, rozciągający się w niej ${ }^{1}$.

\footnotetext{
${ }^{1}$ J. Warszawski, Uniwersalizm. Zarys narodowej filozofii społecznej, Biała Podlaska 2005, s. 39.
} 
Termin , uniwersalizm” w zasobach leksykalnych ujmowany jest jako:

1. dążenie do ogarnięcia pewnej całości, objęcia jakąś działalnością wszystkich ludzi; także cecha tego, co obejmuje sobą całość jakiś spraw, zagadnień itp.; powszechność, 2. postawa i poglądy uznające dominację całości nad częściami, ogółu nad jednostkami itp., przeciwieństwo indywidualizmu i partykularyzmu².

Nieco szerzej kategoria „uniwersalizmu” ujmowana jest w Leksykonie $P W N$, gdzie terminowi temu przypisuje się trzy znaczenia:

po pierwsze: jako „,wszelkie postawy i poglądy uznające dominację całości nad częściami, ogółu nad jednostkami; przeciwieństwo partykularyzmu", po drugie: jako „przekonanie, że ważne wartości, normy i zasady są lub powinny być powszechne", po trzecie: jako „,dążenie do upowszechnienia danego poglądu”

„Uniwersalizm” odnosi się do dyfuzji myśli, teorii filozoficznych. Obejmuje on upowszechnianie techniki i społecznej użyteczności różnego rodzaju przedmiotów oraz rzeczy ${ }^{4}$ „ „Uniwersalne” można zaś pojmować jako to, co jest:

- ponadlokalne, ponadnarodowe, ponadpokoleniowe i jednocześnie przeciwstawne wszelkim partykularyzmom;

- trwate i ciagłe, co stanowi punkt odniesienia dla wielu pokoleń w dziejach ludzkiej kultury;

- wykładnią ładu społecznego, określonym projektem solidarności odnoszącym się do ogótu jednostek tworzacych ludzkie społeczeństwo 5 .

Przywołane powyżej niektóre funkcjonujące w literaturze przedmiotu badań sposoby ujmowania analizowanej kategorii pozwalają traktować ją jako coś, czego nie należy postrzegać w sposób jednoznaczny. Nie istnieje bowiem jeden, jedynie słuszny sposób rozumienia tej kategorii, co znajduje chociażby swoje odzwierciedlenie $\mathrm{w}$ różnych wersjach czy rodzajach uniwersalizmu.

$\mathrm{W}$ prezentowanych $\mathrm{w}$ tym miejscu rozważaniach na uwagę zasługuje pojmowanie uniwersalizmu $\mathrm{w}$ etyce. Zdaniem Haliny Promieńskiej, uniwersalność $\mathrm{w}$ etyce oznacza etykę powszechnie przyjmowaną i akceptowaną, taką etykę, u podstaw której znajduje się wspólny system wartości i norm, określony stan praktyki moralnej, powszechność zgody na określoną teorię prawdy i dobra moralnego. Zatem, etyka uniwersalna to etyka, która obejmuje ogół problemów człowieka, normująca i oceniająca wszyst-

2 Stownik wyrazów obcych, L. Wiśniakowska (opracowanie), Warszawa 2006, s. 976.

${ }^{3}$ Filozofia. Leksykon PWN, Warszawa 2000, s. 339.

${ }_{4}$ Z. Łomny, Człowiek i edukacja wobec przemian globalnych, Opole 1999, s. 66.

${ }^{5}$ A.A. Kotusiewicz, Problemy uniwersalizmu w pedeutologii, [w:] Wspótczesność a kształcenie nauczycieli, red. H. Kwiatkowska, T. Lewowicki, S. Dylak, Warszawa 2000, s. 57. 
kie dziedziny życia, regulująca na przykład życie rodzinne, prywatne, uznająca prymat problemów globalnych nad lokalnymi i indywidualnymi. Wspomniana Autorka odnosi etykę uniwersalną do dwóch jej znaczeń: 1) etyki ogólnoludzkiej, czyli takiej etyki, która odnosi się do wszystkich ludzi; 2) uniwersalizmu etycznego, czyli stanowiska broniącego bezwzględnego charakteru sądów etycznych ${ }^{6}$. Z kolei, Danuta Ślęczek-Czakon wskazuje na znacznie szersze postrzeganie etyki uniwersalnej, ujmując ją w następujących znaczeniach: 1) jako etykę adresowaną do wszystkich ludzi, która obejmuje swymi postulatami wszystkich osobników należących do gatunku homo sapiens; 2) jako etykę adresowaną do wszystkich osobników włączonych do klasy ludzi spełniających przyjęte kryteria człowieczeństwa; 3) jako etykę powszechnie akceptowaną przez ludzi; 4) jako etykę całościową, ogarniającą ogół problemów, oceniającą i normującą wszystkie dziedziny działalności człowieka; 5) jako etykę uznającą prymat problemów globalnych i interesów ogólnoludzkich nad lokalnymi; 6) jako metaetykę w sensie syntezy wszystkich istniejących systemów etycznych; 7) jako etykę głoszącą, że moralność zawsze pozostaje taka sama, rozszerza się tylko krąg ludzi ją akceptujących lub że w każdej moralności występują elementy wspólne; 8) jako etykę stosującą obiektywną, naukową, powszechnie przyjętą metodę uzasadniania racji moralnych, ustalającą powszechne zasady dialogu moralnego ${ }^{7}$. Takie ujęcie etyki uniwersalnej przekonuje o jej dość rozległym ujęciu, co z kolei pozwala na wpisywanie w jej zakres różnorodnych treści, korespondujących z kluczową dla niej problematyką. Najogólniej biorąc, zwolennicy uniwersalizmu w etyce podkreślają, że istnieje zasadnicze podobieństwo moralne ludzi, którzy należą do różnych kultur. Stąd, w konstruowaniu etyki uniwersalnej ważne jest skoncentrowanie się na doświadczeniu i współpracy różnych organizacji, integracji różnych kultur i narodowości, obyczajów i wiar. Chodzi tu o taką etykę, która koncentrować się będzie na tym co wspólne, co ludzi łączy, a nie dzieli, na ich identycznych preferencjach i predylekcjach, doznaniach o odczuciach tego, co pod względem moralnym jest dobre, a co złe?. Etyka Uniwersalna - jak słusznie zauważa Yersu Kim - to: „poszukiwanie wspólnego podłoża war-

\footnotetext{
${ }^{6}$ H. Promieńska, Czy dowartościowanie orzecznikowe etyki jest konieczne? (Między prawda a pewnościa poznania etycznego), [w:] Czy możliwa jest etyka uniwersalna? red. J. Sekuła, Siedlce 1994, s. 257.

${ }^{7}$ D. Ślęczek-Czakon, Czy jest możliwa etyka uniwersalna? Uwagi krytyczne, [w:] Tamże, s. 270271.

${ }^{8} \mathrm{~J}$. Mariański, Między rajem a apokalipsa. O potrzebie wychowania ku wartościom uniwersalnym, [w:] Wychowanie. Pojęcia - procesy - konteksty. Interdyscyplinarne ujęcie, tom 2, red. M. Dudzikowa, M. Czerepaniak-Walczak, Gdańsk 2007, s. 66.

${ }^{9}$ H. Borowski, Blaski i cienie etyki uniwersalnej, [w:] Czy możliwa jest etyka uniwersalna? s. 284.
} 
tości etycznych i norm, będących warunkiem harmonijnego współistnienia i rozkwitu ludzkości"10.

Lech Ostasz, posługując się kategorią nie tyle etyki uniwersalnej, ile etyki uniwersalistycznej (rodzi się pytanie, czy chodzi o etykę uniwersalną czy etykę uniwersalistyczną i na czym polega między nimi różnica, a może założyć, że różnica dotyczy w tym miejscu samego nazewnictwa, a nie treści, jakie niesie z sobą ta etyka), uważa, iż jest to etyka zmierzająca do uniwersalności, czyli taka, która jest w jak największym stopniu wolna od wpływów ideologii politycznej, religii, establishmentu społecznego, jak również presji potoczności, natomiast podstawę jej stanowi jakość życia ludzkiego ${ }^{11}$. Można by w tym miejscu zadać pytanie następującej treści: Czy istnieje możliwość wypracowania takiej uniwersalnej etyki? Odpowiedź na to pytanie nie należy zapewne do prostych, biorąc chociażby pod uwagę pojawiające się niejednokrotnie tendencje i zapatrywania odnośnie etycznego postrzegania współczesnej rzeczywistości społecznej.

Tym niemniej analiza literatury przedmiotu badań przekonuje, iż niejednokrotnie podejmowane były próby skonstruowania takiej etyki, której można byłoby nadać miano uniwersalnej. Dla przykładu można tu podać chociażby projekt Powszechnej Deklaracji Etyki Ogólnoświatowejej ${ }^{12}$ czy też Deklarację globalnej etyki, której współtwórcą i redaktorem jest Hans Küng. W tym ostatnim z wymienionych dokumentów zostały sformułowane cztery zasady etyki globalnej, na których powinna być oparta kultura dzisiejszych i jutrzejszych czasów. Są nimi: 1) Zobowiązanie do kultury nieagresji i szacunku dla życia; 2) Zobowiązanie do kultury solidarności i sprawiedliwego porządku; 3) Zobowiązanie do kultury tolerancji i życia w prawdzie; 4) Zobowiązanie do kultury równych praw i partnerstwa między mężczyznami i kobietami ${ }^{13}$.

Skoro więc etyka uniwersalna obejmuje wszystkie dziedziny życia, stąd można ją również odnieść do uprawiania poszczególnych zawodów, w tym również zawodu nauczycielskiego i jednocześnie zapytać, czy opierając się na wspomnianych powyżej deklaracjach etyki, warto byłoby podjąć trud skonstruowania uniwersalnej etyki nauczycielskiej, a jeśli tak, to co miałoby stanowić jej treść i zakres, jak również, co niezwykle istotne, w jakim stopniu mogłaby ona uporządkowywać etyczny wymiar zawodu nauczycielskiego, który przecież niełatwo poddaje się jednoznacznym kategoryzacjom.

${ }^{10}$ Y. Kim, Kilka myśli o Etyce Uniwersalnej, [w:] Szkoła przeżycia cywilizacyjnego, red. J. Dołęga, J. Kuczyński, A. Woźnicki, Warszawa 1997, s. 157.

${ }^{11}$ L. Ostasz, Ku etyce uniwersalistycznej. Wartości. Zarys aksjologii, Olsztyn 1999, s. 7. s. 170.

${ }^{12}$ L. Swidler, Ku Powszechnej Deklaracji Etyki Światowej, [w:] Szkoła przeżycia cywilizacyjnego,

${ }_{13}$ M. Filipiak, Hansa Künga Koncepcja „światowego ethosu”, [w:] Czy możliwa jest etyka uniwersalna? s. 20-21. 
Odwołując się do wspomnianej wcześniej Deklaracji etyki globalnej, Tadeusz Pilch zadaje dość istotne, biorąc pod uwagę prezentowane w tym miejscu rozważania, pytanie:

Czy ten nowo ustanowiony w naszych czasach kodeks etyki uniwersalnej nie może być podstawą do określenia i formowania cech wychowawcy-nauczyciela oraz społecznego posłannictwa szkoły? ${ }^{14}$

a tym samym i próby dookreślenia etycznego wymiaru zawodu nauczycielskiego w perspektywie uniwersalnej.

Warto w tym miejscu podkreślić, iż jak słusznie zauważa Tadeusz Lewowicki:

Tradycja zawodu nauczycielskiego dostarcza przykładów usilnych starań o ukształtowanie swoistego kanonu norm moralnych właściwych tej profesji. Takie starania wydają się znowu ożywać. Edukację usiłuje się opierać nie tyle na ukształtowaniu u ludzi poczucia wspólnoty opartego na podobnych treściach (treściach kształcenia szkolnego, treściach proponowanych w ramach oświaty pozaszkolnej), co raczej na kształtowaniu poczucia wspólnoty odwołującego się do wartości uniwersalnych. Następuje renesans problematyki aksjologicznej w naukach społecznych, zarysowało się żywo zainteresowanie aksjologią edukacyjną. (...) W refleksji deontologicznej wiele uwagi poświęca się poszukiwaniu elementów stałości czy ciągłości w etyce, w koncepcjach wartości uniwersalnych itp. To one umożliwiają określenie podstaw etyki danej grupy zawodowej, także deontologii nauczycielskiej. Wydaje się, że - co godne jest podkreślenia - podstawy te widzi się w uniwersalnych wartościach moralnych, w obrazie wartości uniwersalnych ${ }^{15}$.

Słowa te wypowiedziane ponad dwadzieścia lat temu do dzisiaj nie straciły na swej aktualności, a przynajmniej w jakimś zakresie. Ciągle bowiem w obszarze działalności zawodowej nauczycieli, a w szczególności jej etycznego wymiaru, pojawiają się kwestie, które wymagają właściwego sobie rozpoznania i tym samym usytuowania na tle problematyki pedeutologicznej czy ściślej etyczno-pedeutologicznej, która w dalszym ciągu wymaga swojego dopełnienia i dookreślenia, chociażby z uwagi na dokonujące się przeobrażenia w obszarze rzeczywistości edukacyjnej, których skutki trudno do końca przewidzieć.

Jak twierdzi przywoływany już nieco wcześniej T. Pilch:

$\mathrm{W}$ świecie ludzkim nic nie jest proste ani jednoznaczne. Ale w chaosie wielości i w świecie nieczytelnych sygnałów winniśmy przyjąć i wyznawać pewne racje i orientacje, które budzą nadzieje ${ }^{16}$.

14 T. Pilch, Spory o szkołę. Pomiędzy tradycją a wyzwaniami wspótczesności, Warszawa 1999, s. 171.

15 T. Lewowicki, Przemiany oświaty. Szkice o ideach i praktyce edukacyjnej, Warszawa 1994, s. $122-123$.

${ }_{16}$ T. Pilch, Spory o szkote, s. 170. 
Słowa te zdają się zaświadczać o możliwej próbie dookreślenia uniwersalnych podstaw etyki zawodu nauczycielskiego. Rozwiązania uniwersalne w obszarze etyki przedstawicieli tego zawodu prowadzić mogą, czy raczej powinny, do ukonstytuowania się tej etyki w postaci kodeksu etycznego. Jednakże, kodeks taki ma zarówno swoich wielu zwolenników, jak i przeciwników, o czym zdaje się w pełni przekonywać analiza literatury przedmiotu badań, wpisująca się w obszar etyczno-pedeutologicznych eksploracji.

Rezygnując $\mathrm{w}$ tym miejscu $\mathrm{z}$ ich przedstawienia, albowiem mogłoby to przekraczać ramy prezentowanych rozważań, warto jednak zaznaczyć, iż sprawa kodeksu etycznego nauczycieli jest na tyle kontrowersyjna, iż jak do tej pory nie ma obowiązującego kodeksu etycznego nauczycieli w wymiarze uniwersalnym. Tym niemniej, pojawiają się próby lepszego bądź gorszego formułowania określonego zestawu czy zestawów obwarowań etycznych (w formie różnych projektów), do których przestrzegania zobligowani byliby przedstawiciele zawodu nauczycielskiego.

W tym miejscu rodzą się jednak kolejne pytania: Czy taki uniwersalny kodeks etyczny charakterystyczny dla środowisk nauczycielskich stanie się lekarstwem na wszelkie bolączki i choroby moralne dotykające przedstawicieli tego jakże szlachetnego zawodu? Czy byłby on w stanie uzdrowić moralnie nauczycieli? Na ile, w jakim stopniu i zakresie nauczyciele staliby się bardziej moralni w obszarze podejmowanej przez siebie aktywności zawodowej? Czy tylko kodeks etyczny wystarczy tej kategorii społeczno-zawodowej do tego, aby postępować zgodnie z jego zapisami? Odpowiedź na te pytania zdaje się być złożona i zapewne niejednoznaczna, a co za tym idzie - również niezwykle polemiczna. Stąd też można dostrzec potrzebę poszukiwania innych, aniżeli ściśle kodeksowe, rozwiązań problemów natury etycznej odnoszących się do aktywności reprezentantów zawodu nauczycielskiego.

\section{Pluralistyczna etyka zawodowa nauczycieli}

Kategoria „pluralizm” zyskała szczególnie w naszym kraju swoistą popularność, żeby nie powiedzieć wręcz oszałamiającą, po przemianach, których początek datuje się na połowę 1989 roku, kiedy to partia komunistyczna poniosła klęskę $\mathrm{w}$ pierwszych quasi wolnych wyborach. Od tego okresu mamy bowiem w szczególności do czynienia z wieloma napływającymi, różnorodnymi koncepcjami rzeczywistości społecznej i elementami ją konstytuującymi.

Termin ,,pluralizm” zgodnie z ustaleniami słownikowymi to:

1. demokratyczna zasada ustrojowa, gwarantująca różnym grupom społecznym i politycznym prawo wyrażania swych interesów (politycznych, społecznych i ekonomicznych) oraz udział w sprawowaniu władzy; 2 . współistnienie wielu różnych opinii i norm w tym samym społeczeństwie lub systemie; różnorodność, wielość, zróżnico- 
wanie; 3. stanowisko w dziedzinie ontologii, według którego rzeczywistość nie daje się sprowadzić do jednej zasady, lecz musi być wyjaśniana przez ich wielość; 4 . stanowisko głoszące istnienie $\mathrm{w}$ świecie mnogości samoistnych bytów rzeczywistych, związanych z realizmem ontologicznym, przeciwstawne monizmowi ${ }^{17}$.

W Leksykonie PWN pluralizm rozumiany jest jako:

pogląd z dziedziny metafizyki przeciwstawny monizmowi, według którego w rzeczywistości lub w poznaniu istnieje (działa) wiele różnych, niezależnych od siebie, podstawowych elementów - substancji, zasad, czynników, sił; każdy istniejący byt jednostkowy jest odrębną strukturą, niesprowadzalną do jednego wspólnego tworzywa wszystkich bytów którego istnienie pluralizm neguje; pluralizm wynika z przekonania, że odrębność i jedność są właściwością każdego bytu $(\ldots)^{18}$.

Funkcjonujące w dostępnych zasobach leksykalnych znaczenia nadawane terminowi „,pluralizm” pozwalają pojmować go jako - najogólniej biorąc zróżnicowanie, niejednorodność, wielość. Tymczasem, zagłębiając się w rozumienie tej kategorii, można dostrzec jej szersze i nieco bardziej ściślejsze pojmowanie.

Pluralizm sensu largo oznacza zróżnicowanie, bogactwo elementów, które połączone są w niesprzeczną całość; owo zróżnicowanie jest funkcjonalne ze względu na powstanie, trwanie oraz rozwój układu. Natomiast, pluralizm sensu stricto dotyczy świata człowieka i oznacza system zróżnicowanych zjawisk, wartości i dóbr świadomie ustrukturowany jako całość niesprzeczna i funkcjonalna ${ }^{19}$. Analizując kategorię pluralizmu, nie sposób nie dostrzec jej wielowymiarowości znaczeniowej, która pozwala na przymiotnikowe jej wzbogacenie. Stąd też można mówić między innymi o pluralizmie społecznym, pluralizmie religijnym, pluralizmie aksjologicznym, pluralizmie kulturowym, czy też pluralizmie politycznym ${ }^{20}$. Wszystkie one zdają się funkcjonować w mniejszym bądź większym zakresie w przestrzeni publicznej społeczeństwa określanego mianem pluralistycznego.

Rację ma Mariusz Wojewoda stwierdzając, że:

Współczesny pluralizm rozumiany jest jako wielość indywidualnych postaw lub szerzej: modeli teoretycznych, za których pomocą opisuje się złożony charakter zjawisk kulturowych, etycznych, religijnych ${ }^{21}$.

17 Stownik wyrazów obcych, s. 735.

${ }^{18}$ Filozofia, Leksykon PWN, s. 260.

${ }^{19}$ W. Gołaszewski, Pluralizm kulturowy: zjawisko i wartość, [w:] Pluralizm w kulturze polskiej, red. F. Adamski, Kraków 1988, s. 182.

${ }^{20}$ F. Adamski, Pluralizm, [w:] Encyklopedia pedagogiczna XXI wieku, tom IV, red. T. Pilch, Warszawa 2005, s. 404-405.

${ }^{21}$ M. Wojewoda, Pluralizm aksjologiczny i jego implikacje we wspótczesnej filozofii i religii, Katowice 2010, s. 9. 
Interesujące podejście do zagadnienia pluralizmu prezentuje Franciszek Adamski, odnosząc go do trzech odmiennych sytuacji: 1) gdy w obrębie jednej społecznej czy kulturowej całości mamy do czynienia ze zjawiskiem zróżnicowania i heterogeniczności, zatem ze zjawiskiem pluralizmu mamy do czynienia wówczas, kiedy w obrębie danej zbiorowości pojawia się rozmaitość typów, cech stanowiących ją członków; niejednorodność ich poglądów, czy też dążeń oraz wartości; 2) obejmujący postawę, która charakteryzuje się otwartością, czy wręcz życzliwością wobec wszelkiej różnorodności i inności; 3) odnoszący się do form zewnętrznych, przy jednorodności ich wewnętrznych znaczeń, czyli chodzi tu o jedność wewnętrzną treści przy różnorodności form ich przeżywania i manifestowania ${ }^{22}$. Jak podkreśla Beata Polanowska-Sygulska:

Na gruncie pluralizmu fundamentalne ludzkie wartości są obiektywne i poznawalne, ale jest ich wiele. Owa wielość nie poddaje się ani redukcji, ani pełnemu hierarchicznemu uporządkowaniu, które byłoby uniwersalnie prawomocne ${ }^{23}$.

Nie można jednak zapominać, iż mówiąc o pluralizmie należy odnieść się do wartości uniwersalnych. Wspomina o tym przywołany nieco wcześniej F. Adamski, charakteryzując społeczeństwo pluralistyczne w sposób następujący:

Jak każde zdrowe społeczeństwo, tak też społeczeństwo pluralistyczne nie może być pozbawione fundamentu nienaruszalnych wartości - wartości uniwersalnych. One stanowią konieczny warunek rozwoju osoby ludzkiej i prawdziwie ludzkiej kultury. Pluralizm może być wyrazem i podstawą bogactwa i zdrowia danej kultury, ale może też być źródłem dezintegracji kultury, jej rozpadu, zatraty jej tożsamości ${ }^{24}$.

Zaprezentowane podejścia do kategorii pluralizmu implikują określone postrzeganie etyki zawodowej, również nauczycielskiej.

Odnosząc się do powyższych spostrzeżeń, należy mieć na względzie, że etyka zawodowa nauczycieli pozostaje wytworem czynników światopoglądowych, ustrojowych, ekonomicznych, społecznych, jednostkowych, profesjonalnych, prywatnych ${ }^{25}$. Ten zestaw czynników kształtujących etykę zawodową nauczycieli zdaje się właściwie uzupełniać Andrzej Dróżdż podkreślając, iż:

${ }^{22}$ F. Adamski, Pluralizm, s. 405; tenże, Pluralizm wartości a wychowanie, Kwartalnik Naukowy Fides et Ratio, 2011, 3, s. 80-81.

${ }^{23}$ B. Polanowska-Sygulska, Pluralizm wartości i jego implikacje w filozofii prawa, Kraków 2008, s. 26 .

${ }^{24}$ F. Adamski, Pluralizm, s. 407.

${ }^{25}$ K. Duraj-Nowakowa, Dymorfizm etyczno-deontologiczny wspótczesnych nauczycieli, [w:] Problemy etyczno-deontologiczne zawodu nauczycielskiego w okresie przemian ustrojowych w Polsce, red. A.M. Tchorzewski, Bydgoszcz 1993, s. 61. 
W każdej epoce obok uniwersalnych i ahistorycznych treści, wyrastających niejako z archetypu przekazywania adeptom wiedzy o świecie, na etykę nauczycieli oddziaływały liczne czynniki historyczne, warunki społeczno-ustrojowe, istniejący poziom wiedzy, materialne warunki pracy nauczycieli, wrażliwość moralna całego społeczeństwa i szereg innych czynników kulturowych, moralnych, materialnych czy religijnych ${ }^{26}$.

Te i zapewne wiele jeszcze innych uwarunkowań mogą przemawiać za potrzebą różnorodnych sposobów postrzegania etyki zawodu nauczycielskiego, zarówno w zakresie jej treści, jak i formy. To właśnie te czynniki, o których pisze wspomniany wcześniej Autor, skłaniają ku postrzeganiu etyki zawodowej nauczycieli w wersji pluralistycznej.

Stąd, dla podejmowanych rozważań istotne znaczenie ma kategoria pluralizmu aksjologiczno-etycznego. Przywoływany nieco wcześniej M. Wojewoda uważa, iż:

jest on stanowiskiem, które wyodrębniło się w ramach sporu o obiektywny status wartości i zasad etycznych, mieszczących się pośrodku między relatywizmem (skrajnym sytuacjonizmem), kwestionującym istnienie obiektywnych wartości i zasad, a absolutyzmem etycznym (skrajnym pryncypializmem), przyjmującym istnienie zasad, które obowiązują bezwyjątkowo, niezależnie od miejsca, czasu i okoliczności. W takim ujęciu pluralizm etyczny jest stanowiskiem normatywnym, którego zwolennicy porządkują świat wartości i norm etycznych, unikając wskazanych wcześniej skrajności ${ }^{27}$.

Pluralistycznie ujęta etyka zawodowa nauczycieli nie jest zatem etyką odrzucającą wszelkie obwarowania etyczne przypisywane tej profesji, ale przyjmuje, iż tych obwarowań jest wiele. Stąd też nie ma jednych i jedynie słusznych uregulowań etycznych, których mają przestrzegać nauczyciele w trakcie podejmowanej przez siebie aktywności zawodowej, a to z kolei oznacza, iż nie ma jedynie słusznych rozstrzygnięć w sferze moralnej, co wcale nie oznacza dowolności czy wręcz dobrowolności takowych rozstrzygnięć. Wydaje się, iż taka całkowita swoboda w obszarze etycznego wymiaru zawodu nauczyciela nie do końca jest uzasadniona. Zatem, wszelkie rozwiązania kwestii natury etycznej zawsze pozostawać powinny w określonych granicach (lepiej lub gorzej, ale zawsze ustalonych) niekoniecznie wyznaczonych przez jedynie słuszne normy czy też inne obwarowania etyczne, ale przez wzgląd na istnienie ich wielości w obszarze nauczycielskiej działalności zawodowej w jego wymiarze etycznym. Wszystko to wskazuje na konieczność istnienia w zawodzie nauczycielskim określonych

${ }^{26}$ A. Dróżdż, Etyka nauczycieli, [w:] Etyczny wymiar edukacji nauczycielskiej, red. A. Rumiński, Kraków 2004, s. 53.

${ }_{27}$ M. Wojewoda, Pluralizm aksjologiczny i jego implikacje, s. 51. 
uregulowań natury etycznej, z jednym istotnym zastrzeżeniem, iż takich uregulowań jest wiele, na przykład w zależności od przyjmowanych założeń, głoszonych stanowisk, zapatrywań i tym podobnych.

\section{Próba synkretycznego ujmowania etyki zawodowej nauczycieli}

$\mathrm{Na}$ kanwie przedłożonych rozważań rodzi się pytanie następującej treści: czy istnieje możliwość/szansa wypracowania etyki zawodowej nauczyciela ujmowanej jednocześnie zarówno z perspektywy uniwersalnej, jak i pluralistycznej? Odpowiedź na to pytanie nie należy zapewne do łatwych, a tym bardziej niepolemicznych, wszak odnosi się do materii, która trudno poddaje się jednoznacznym ustaleniom. Wszystko bowiem uzależnione jest od przyjmowanych podstaw teoretycznych i własnych sposobów postrzegania charakteru oraz kształtu tejże etyki, a czasami wręcz i panującej aktualnie mody odnośnie ujmowania etyki zawodowej nauczycieli. Tym niemniej, warto przytoczyć niektóre argumenty przemawiające za możliwością synkretycznego podejścia do etyki reprezentantów zawodu nauczycielskiego.

Uzasadnienia dla próby pogodzenia ze sobą uniwersalizmu i pluralizmu dostrzec można w rozważaniach Janusza Kuczyńskiego, który uważa, iż uniwersalizm we współczesnej wersji jest komplementarny wobec pluralizmu, wzajemnie się z nim warunkując. Uniwersalizm bez pluralizmu staje się totalizmem i w społecznych konsekwencjach totalitaryzmem; pluralizm bez uniwersalizmu staje się indywidualizmem, w społecznych konsekwencjach zaś anarchizmem ${ }^{28}$. Zatem, przeciwstawienie sobie uniwersalizmu i pluralizmu nie do końca wydaje się słuszne. Jak twierdzi Bogusław Śliwerski, nie można mówić o wielości bez jedności ${ }^{29}$. Można to odnieść również do etycznego wymiaru przedstawicieli zawodu nauczycielskiego.

W odniesieniu bowiem do nauczycieli, uznanie uniwersalności obwarowań etycznych nie musi wiązać się z porzuceniem etosu polskiego nauczyciela. Uniwersalizm uznaje pluralizm, ponieważ całość nie może być homogeniczna, gdyż grozi to totalitaryzmem ${ }^{30}$. Z kolei, uznanie różnorodności nie musi przecież prowadzić do porzucenia norm i wartości, w szczególności zaś, gdy pluralizm, zwłaszcza aksjologiczny czy etyczny, potraktujemy jako ogól-

\footnotetext{
28 J. Kuczyński, Wstęp do uniwersalizmu, tom I - Ogrodnicy świata, Warszawa 1998, s. 10.

${ }^{29}$ B. Śliwerski, Wspótczesna myśl pedagogiczna. Znaczenia, klasyfikacje, badania, Kraków 2009, s. 50 .

${ }^{30}$ D. Ślęczek-Czakon, Czy jest możliwa etyka uniwersalna? Uwagi krytyczne, [w:] Czy możliwa jest etyka uniwersalna? s. 268.
} 
noludzką wartość wpisaną w kulturę moralną ${ }^{31}$. Nie sposób nie zgodzić się, iż: (...) uznanie różnorodności nie musi prowadzić do relatywizmu wartości i norm ${ }^{32}$. Rację ma zapewne Marian Golka stwierdzając:

Nie sposób precyzyjnie określić proporcji między cechami jednorodnymi a różnorodnymi we współczesnym świecie. Ba, nie sposób rozdzielić uniwersalizmu i pluralizmu obecnych w tym świecie, jako że są one wzajemnie ze sobą powiązane i współzależne ${ }^{33}$.

Przytoczenie powyższych argumentów zdaje się przesądzać o tym, iż istnieje możliwość synkretycznego podejścia do etyki zawodu nauczycielskiego. Kto jednak miałby skonstruować taką etykę, co stanowiłoby jej treść, jaki byłby jej zakres oraz czy i na ile odnalazłaby ona swoje odzwierciedlenie w praktyce moralnej uprawiania zawodu nauczycielskiego?

Dla podejmowanych rozważań istotna może być kategoria określana mianem pluralizmu uniwersalnego, która swym zasięgiem obejmuje wiele kultur, wiele narodów. Taki pluralizm wymaga pewnego minimalnego zbioru wspólnych norm, mega-etosu, integrującego i łączącego wielość orientacji, między innymi kulturowych. Wspominany mega-etos złożony z wartości centralnych, uogólnionych powszechnie znanych symboli, podzielanych przez dużą część ludności, tworzy właśnie minimalny zbiór norm funkcjonalnego systemu pluralistycznego ${ }^{34}$.

Próba zaaplikowania kategorii pluralizmu uniwersalnego na grunt nauczycielskiej etyki zawodowej implikuje nieco odmienny sposób jej postrzegania, aniżeli w wersji ,"czysto" uniwersalnej czy pluralistycznej, przybierając tym samym postać, najogólniej biorąc, umiarkowanego uniwersalizmu i jednocześnie pluralizmu. Stąd, taka perspektywa ujmowania etyki nauczycielskiej nie oznacza całkowitego odrzucania tej etyki w formie najogólniejszych, zróżnicowanych wytycznych, które mogłyby, również w sposób najogólniejszy, uporządkowywać moralną działalność środowisk nauczycielskich, uwzględniając tym samym jej doniosłe i ważne znaczenie, zarówno w obszarze teorii, jak i praktyki edukacyjnej.

\section{Zakończenie}

Przedstawione powyżej rozważania, prowadzone wprawdzie na płaszczyźnie wyłącznie teoretycznej, mają jednakże swoje implikacje dla praktyki edukacyjnej. Rezygnując w tym miejscu z pogłębionych studiów i analiz od-

\footnotetext{
31 J. Sekuła, O naturze i formowaniu etyki uniwersalnej, [w:] Tamże, s. 48.

${ }^{32}$ Y. Kim, Kilka myśli o Etyce Uniwersalnej, [w:] Szkoła przeżycia cywilizacyjnego, s. 158.

${ }_{33}$ M. Golka, Cywilizacja. Europa. Globalizacja, Poznań 1999, s. 116.

${ }^{34}$ F. Gross, Tolerancja i pluralizm, Warszawa 1992, s. 66.
} 
nośnie praktycznego wymiaru działalności zawodowej nauczycieli, warto dostrzec, iż zdają się stawiać współczesnego nauczyciela przed nie lada dylematem natury etycznej, a mianowicie, czy ma on kierować się w ramach podejmowanej przez siebie aktywności zawodowej jakimiś ustanowionymi przez kogoś obwarowaniami etycznymi, a jeśli już tak, to przez kogo (?), czy może opowiadać się za wielością równoległego funkcjonowania wielu różnych takich obwarowań, czy może przyjmując wielość rozwiązań w sferze moralnej, mieć na uwadze na to, iż wiele $z$ nich ma swój wspólny fundament zakorzeniony w historii i tradycji ludzkości, a tym samym i zawodu nauczycielskiego. Można by więc zaryzykować stwierdzenie, iż etyka zawodu nauczycielskiego nadal znajduje się w stanie in statu nascendi. Jak zmienić taki stan rzeczy? Wydaje się, iż kwestia ta pozostaje ciągle otwarta, a tym samym wymaga dalszego rozpoznawania, zarówno w perspektywie aktualnych, jak i przyszłościowych wyzwań edukacyjnych, w szczególności zaś pedeutologicznych.

\section{BIBLIOGRAFIA}

Adamski F., Pluralizm, [w:] Encyklopedia pedagogiczna XXI wieku, t. IV, red. T. Pilch, Wydawnictwo Akademickie Żak, Warszawa 2005.

Adamski F., Pluralizm wartości a wychowanie, Kwartalnik Naukowy Fides et Ratio, 2011, 3.

Borowski H., Blaski i cienie etyki uniwersalnej, [w:] Czy możliwa jest etyka uniwersalna? red. J. Sekuła, Wydawnictwo Wyższej Szkoły Rolniczo-Pedagogicznej, Siedlce 1994.

Dróżdż A., Etyka nauczycieli, [w:] Etyczny wymiar edukacji nauczycielskiej, red. A. Rumiński, Oficyna Wydawnicza Impuls, Kraków 2004.

Duraj-Nowakowa K., Dymorfizm etyczno-deontologiczny wspótczesnych nauczycieli, [w:] Problemy etyczno-deontologiczne zawodu nauczycielskiego w okresie przemian ustrojowych $w$ Polsce, red. A.M. Tchorzewski, Wydawnictwo Uczelniane Wyższej Szkoły Pedagogicznej w Bydgoszczy, Bydgoszcz 1993.

Filipiak M., Hansa Künga Koncepcja „światowego ethosu”, [w:] Czy możliwa jest etyka uniwersalna? red. J. Sekuła, Wydawnictwo Wyższej Szkoły Rolniczo-Pedagogicznej, Siedlce 1994.

Filozofia. Leksykon PWN, Wydawnictwo Naukowe PWN, Warszawa 2000.

Golka M., Cywilizacja. Europa. Globalizacja, Wydawnictwo Fundacji Humaniora, Poznań 1999.

Gołaszewski W., Pluralizm kulturowy: zjawisko i wartość, [w:] Pluralizm w kulturze polskiej, red. F. Adamski, Wydawnictwo Uniwersytetu Jagiellońskiego, Kraków 1988.

Gross F., Tolerancja i pluralizm, IFiS PAN, Warszawa 1992.

Kim Y., Kilka myśli o Etyce Uniwersalnej, [w:] Szkoła przeżycia cywilizacyjnego, red. J. Dołęga, J. Kuczyński, A. Woźnicki, ,Wydawnictwo Naukowe Scholar, Warszawa 1997.

Kotusiewicz A.A., Problemy uniwersalizmu w pedeutologii, [w:] Wspótczesność a kształcenie nauczycieli, red. H. Kwiatkowska, T. Lewowicki, S. Dylak, Wydawnictwo i Zakład Poligrafii Technologii Eksploatacji, Warszawa 2000.

Kuczyński J., Wstęp do uniwersalizmu, tom I - Ogrodnicy świata, Centrum Uniwersalizmu przy Uniwersytecie Warszawskim: Wyższa Szkoła Ekologii i Zarządzania, Warszawa 1998. 
Lewowicki T., Przemiany oświaty. Szkice o ideach i praktyce edukacyjnej, Wydawnictwo Akademickie Żak, Warszawa 1994.

Łomny Z., Człowiek i edukacja wobec przemian globalnych, Wydawnictwo Uniwersytetu Opolskiego, Opole 1999.

Mariański J., Między rajem a apokalipsa. O potrzebie wychowania ku wartościom uniwersalnym, [w:] Wychowanie. Pojęcia - procesy - konteksty. Interdyscyplinarne ujęcie, tom 2, red. M. Dudzikowa, M. Czerepaniak-Walczak, Gdańskie Wydawnictwo Psychologiczne, Gdańsk 2007.

Ostasz L., Ku etyce uniwersalistycznej. Wartości. Zarys aksjologii, Wydawnictwo Olsztyńskiej Szkoły Wyższej, Olsztyn 1999.

Pilch T., Spory o szkotę. Pomiędzy tradycja a wyzwaniami wspótczesności, Wydawnictwo Akademickie Żak, Warszawa 1999.

Polanowska-Sygulska B., Pluralizm wartości i jego implikacje w filozofii prawa, Księgarnia Akademicka. Ośrodek Myśli Politycznej, Kraków 2008.

Promieńska H., Czy dowartościowanie orzecznikowe etyki jest konieczne? (Między prawdą a pewnościa poznania etycznego), [w:] Czy możliwa jest etyka uniwersalna? red. J. Sekuła, Wydawnictwo Wyższej Szkoły Rolniczo-Pedagogicznej, Siedlce 1994.

Sekuła J., O naturze i formowaniu etyki uniwersalnej, [w:] Czy możliwa jest etyka uniwersalna? red. J. Sekuła, Wydawnictwo Wyższej Szkoły Rolniczo-Pedagogicznej, Siedlce 1994.

Stownik wyrazów obcych, L. Wiśniakowska (opracowanie), Wydawnictwo Naukowe PWN, Warszawa 2006.

Swidler L., Ku Powszechnej Deklaracji Etyki Światowej, [w:] Szkoła przeżycia cywilizacyjnego, red. J. Dołęga, J. Kuczyński, A. Woźnicki, Wydawnictwo Naukowe Scholar, Warszawa 1997.

Ślęczek-Czakon D., Czy jest możliwa etyka uniwersalna? Uwagi krytyczne, [w:] Czy możliwa jest etyka uniwersalna? red. J. Sekuła, Wydawnictwo Wyższej Szkoły Rolniczo-Pedagogicznej, Siedlce 1994.

Śliwerski B., Współczesna myśl pedagogiczna. Znaczenia, klasyfikacje, badania, Oficyna Wydawnicza Impuls, Kraków 2009.

Warszawski J., Uniwersalizm. Zarys narodowej filozofii społecznej, Agencja Wydawniczo-Reklamowa „Arte”, Biała Podlaska 2005.

Wojewoda M., Pluralizm aksjologiczny i jego implikacje we wspótczesnej filozofii i religii, Wydawnictwo Uniwersytetu Śląskiego, Katowice 2010. 